\title{
A hierarchical framework for index computation in sustainable manufacturing
}

\author{
Ocampo, Lanndon A. ${ }^{\mathrm{a}, *}$ \\ ${ }^{a}$ University of San Carlos, Department of Mechanical Engineering, Cebu City, Cebu, Philippines
}

\section{A B S T R A C T}

Environmental regulations, the desire for market leadership and social stewardship along with pressing environmental crises have shifted manufacturing industries from focusing on traditional, purely profit-based strategies into pursuing the sustainability of manufactured products and manufacturing processes. However, assessing the sustainability levels of manufacturing industries poses a challenge due to the lack of holistic methods when in performing such assessments. In this area, current literature has embarked on computing an aggregate index for assessing sustainability performance. Nevertheless, approaches in computing sustainable manufacturing index are scarce in the literature. This paper presents a preliminary framework for computing a sustainable manufacturing index using the analytic hierarchy process. In this context, sustainability is interpreted from a triple-bottom line approach and the set of elements that comprise the index obtained from the US National Institute of Standards and Technology sustainable manufacturing repository. The use of this repository highlights a holistic approach in aggregate index computation as it offers a comprehensive list of elements of the triple-bottom line within the context of the manufacturing industry. Preliminary results have provided valuable insights into measuring sustainable manufacturing levels and could serve as a basic framework for index computation. The contribution of this work is on presenting a simple yet holistic approach towards computing a sustainable manufacturing index.
\end{abstract}

\section{ARTICLE INFO}

Keywords:

Manufacturing

Sustainability

Index computation

Analytic hierarchy process

*Corresponding author: don_leafriser@yahoo.com (Ocampo, Lanndon A.)

Article history:

Received 5 February 2015

Revised 12 February 2015

Accepted 1 March 2015

(C) 2015 PEI, University of Maribor. All rights reserved. 


\title{
Hierarhični okvir za izračun stopnje trajnostne proizvodnje
}

\author{
Ocampo, Lanndon A. ${ }^{a,}$ \\ ${ }^{a}$ University of San Carlos, Department of Mechanical Engineering, Cebu City, Cebu, Philippines
}

\begin{abstract}
POVZETEK
Okoljski predpisi, konkurenčnost in socialna odgovornost so skupaj z okoljevarstvenimi zahtevami preusmerili proizvodno dejavnost od strategij, ki temeljijo le na dobičku, k zasledovanju trajnostnih učinkov industrijskih izdelkov in proizvodnih postopkov. Vrednotenje trajnostnih ciljev predstavlja izziv zaradi pomanjkanja celostne obravnave področja. Obstoječi viri, ki so precej redki, se vrednotenja lotevajo z računanjem skupne stopnje za ocenjevanje uspešnosti trajnostnega razvoja. $V$ članku je predstavljen preliminarni okvir za izračunavanje stopnje trajnostne proizvodnje s pomočjo analitičnega hierarhičnega postopka. Trajnostna proizvodnja je vrednotena s tremi cilji (tj. okoljskimi predpisi, konkurenčnostjo in socialno odgovornostjo) in temelji na pristopu od spodaj navzgor, vsebuje pa elemente iz zbirke napotkov ameriškega nacionalnega inštituta za standarde in tehnologijo (angl. US National Institute of Standards and Technology sustainable manufacturing repository). Uporaba zbirke napotkov obsega celosten pristop pri agregatnem izračunu stopnje, saj ponuja celovit seznam elementov treh poglavitnih ciljev trajnostne proizvodnje. Preliminarni rezultati so omogočili koristen vpogled v kakovost določanja stopnje trajnostne proizvodnje in lahko služijo kot osnovni okvir za izračun stopnje trajnostne proizvodnje. Članek tako predstavi preprost in celosten način za izračun stopnje trajnostne proizvodnje.
\end{abstract}

\section{PODATKI O ČLANKU}

Ključne besede: Proizvodnja

Trajnostni razvoj

Izračun stopnje

Analitični hierarhični postopek

*Kontaktna oseba: don_leafriser@yahoo.com (Ocampo, Lanndon A.)

Zgodovina članka:

Prejet 5. februarja 2015

Popravljen 12. februarja 2015

Sprejet 1. marca 2015 


\section{References}

[1] Rosen, M.A., Kishawy, H.A. (2012). Sustainable manufacturing and design: Concepts, practices and needs, Sustainability, Vol. 4, No. 2,154-174, doi: 10.3390/su4020154.

[2] Joung, C.B., Carrell, J., Sarkar, P., Feng, S.C. (2013). Categorization of indicators for sustainable manufacturing, Ecological Indicators, Vol. 24, 148-157, doi: 10.1016/j.ecolind.2012.05.030.

[3] International Trade Administration. How Does Commerce Define Sustainable Manufacturing? U.S. Department of Commerce, from http://www.trade.gov/competitiveness/sustainablemanufacturing/how_doc_defines_SM.asp, accessed February 12, 2015.

[4] Jayal, A.D., Badurdeen, F., Dillon, O.W. Jr., Jawahir, I.S. (2010). Sustainable manufacturing: Modeling and optimization challenges at the product, process and system levels, In: D. Tichkiewitch, S., Brissaud, (ed.), CIRP Journal of Manufacturing Science and Technology, Vol. 2, No. 3, 144-152, doi: 10.1016/j.cirpj.2010.03.006.

[5] International Institute for Sustainable Development (IISD), Deloitte \& Touche, Business Council for Sustainable Development (1992). Business strategy for sustainable development: Leadership and accountability for the '90s, International Institute for Sustainable Development, Winnipeg, Canada, doi: 10.1002/bse.3280030307.

[6] Dyllick, T., Hockerts, K. (2002). Beyond the business case for corporate sustainability, Business Strategy and the Environment, Vol. 11, No. 2, 130-141, doi: $10.1002 /$ bse.323.

[7] Van Marrewijk, M. (2003). Concepts and definitions of CSR and corporate sustainability: Between agency and communion, Journal of Business Ethics, Vol. 44, No. 2-3, 95-105, doi: 10.1023/A:1023331212247.

[8] Labuschagne, C., Brent, A.C., Van Erck, R.P.G. (2005). Assessing the sustainability performances of industries, Journal of Cleaner Production, Vol. 13, No. 4, 373-385, doi: 10.1016/i.jclepro.2003.10.007.

[9] Roca, L.C., Searcy, C. (2012). An analysis of indicators disclosed in corporate sustainability reports, Journal of Cleaner Production, Vol. 20, No. 1, 103-118, doi: 10.1016/i.jclepro.2011.08.002.

[10] Global reporting initiative (2011). Sustainability Reporting Guidelines, version 3.1, from https://www. globalreporting.org/resourcelibrary/g3.1-guidelines-incl-technical-protocol.pdf, accessed February 12, 2015.

[11] SAM Index. The Dow Jones sustainability index, from http://www.sustainability-indices.com/, accessed February $12,2015$.

[12] Institution of Chemical Engineers (2012). The sustainability metrics: Sustainable development, progress metrics recommended for use in the process industries, from $h t t p: / / n b i s . o r g /$ nbisresources/metrics/triple_bottom_line_ indicators_process_industries.pdf, accessed February 12, 2015.

[13] United Nations (2007). Indicators of sustainable development: Guidelines and methodologies, $3^{\text {rd }}$ edition, United Nations Publication, New York, USA, from http://www.un.org/esa/sustdev/natlinfo/indicators/guidelines.pdf, accessed February 12, 2015.

[14] Spangenberg, J.H., Bonniot, O. (1998). Sustainability indicators - A compass on the road towards sustainability, Wuppertal paper No. 81, Wuppertal Institute for Climate, Environment, and Energy, Wuppertal, Germany, from http://www.ulb.ac.be/ceese/STAFF/Tom/spangenberg.pdf, accessed February 12, 2015.

[15] Environmental Sustainability Indicators. 2005 environmental sustainability index - Benchmarking national environmental stewardship, Yale Center for Environmental Law and Policy, Yale University; Center for International Earth Science Information Network, Columbia University, from http://www.yale.edu/esi/ESI2005_Main_ Report.pdf, accessed February 12, 2015.

[16] European Environment Agency (2005). EEA core set of indicators - Guide, Technical Report No. 1/2005, from http://www.eea.europa.eu/publications/technical_report_2005_1, accessed February 12, 2015.

[17] 2010 Environmental Performance Index. Yale Center for Environmental Law \& Policy, Yale University; Center for International Earth Science Information Network (CIESIN), Columbia University; World Economic Forum, Geneva; Joint Research Center of the European Commission, Italy, from http://www.ciesin.org/documents/ EPI_2010_report.pdf, accessed February 12, 2015.

[18] OECD Environmental Indicators: Development, Measurement and Use. Organisation for Economic, Co-operation and Development, from $h t t p: / / w w w . o e c d . o r g / e n v i r o n m e n t / i n d i c a t o r s-m o d e l l i n g-o u t l o o k s / 24993546 . p d f$, accessed February 12, 2015.

[19] Science and Technology Indicator Project Team, National Institute of Science and Technology Policy (NISTEP), Science and Technology Agency, Japan (1995). Science and technology indicators: 1994 - A systematic analysis of science and technology activities in Japan, National Institute of Science and Technology, Japan, from http://www.nistep.go.jp/achiev/ftx/eng/rep037e/pdf/rep037e.pdf, accessed February 12, 2015.

[20] Schmidt, W.-P., Taylor, A. (2006). Ford of Europe's product sustainability index, In: Proceedings of $13^{\text {th }}$ CIRP International Conference on Life Cycle Engineering, Leuven, Belgium, 5-10.

[21] Towards Environmental Pressure Indicators for the EU, Environment and Energy Paper Theme 8, Luxemborg, European Commission, http://www.iisd.org/measure/compendium/DisplayInitiative.aspx?id=472, accessed February 12, 2015.

[22] Feng, S.C., Joung, C.-B., Li, G. (2010). Development overview of sustainable manufacturing metrics, In: Proceedings of the 17th CIRP International Conference on Life Cycle Engineering 2010, Hefei, China, 6-12.

[23] Dreher, J., Lawler, M., Stewart, J., Strasorier, G., Thorne, M. (2009). General Motors - Metrics for sustainable manufacturing, MIT Sloan School of Management, Cambridge, USA, from http://mitsloan.mit.edu/actionlearning/ media/documents/s-lab-projects/GM-report.pdf, accessed February 12, 2015.

[24] INSEAD (2011), Wal-Mart's sustainable product index, from http://centres.insead.edu/social-innovation/whatwe-do/documents/5751-WalMart-A-CS-EN-0-07-2011-w.pdf, accessed February 12, 2015. 
[25] International Organization for Standardization (ISO). Environmental management - Environmental performance evaluation - Guidelines, ISO 14031:1999(en), Geneva, Switzerland.

[26] Gupta, A., Vangari, R., Jayal, A.D., Jawahir, I.S. (2011). Priority evaluation of product metrics for sustainable manufacturing, In: Bernard, A. (ed.), Global Product Development, Springer-Verlag Berlin Heidelberg, Germany, 631641, doi: $10.1007 / 978-3-642-15973-263$.

[27] National Institute of Standards and Technology, Sustainable Manufacturing Indicator Repository (SMIR), from http://www.nist.gov/el/msid/smir.cfm, accessed February 12, 2015.

[28] Lee, K.-H., Saen, R.F. (2012). Measuring corporate sustainability management: A data envelopment analysis approach, International Journal of Production Economics, (Sustainable development of manufacturing and services), Vol. 140, No. 1, 219-226, doi: 10.1016/j.ijpe.2011.08.024.

[29] De Silva, N., Jawahir, I.S., Dillon, O. Jr., Russel, M. (2006). A new comprehensive methodology for the evaluation of product sustainability at the design and development stage of consumer electronic products, In: Proceedings of $13^{\text {th }}$ CIRP International Conference on Life Cycle Engineering, Leuven, Belgium, 335-340.

[30] Ghadimi, P., Azadnia, A.H., Yusof, N.M., Saman, M.Z.M. (2012). A weighted fuzzy approach for product sustainability assessment: A case study in automotive industry, Journal of Cleaner Production, Vol. 33, 10-21, doi: 10.1016/ j.jclepro.2012.05.010.

[31] Jaafar, I.H., Venkatachalam, A., Joshi, K., Ungureanu, A.C., De Silva, N., Rouch, K.E., Dillon, O.W. Jr., Jawahir, I.S. (2007). Product design for sustainability: A new assessment methodology and case studies, In: Kutz, M. (ed.), Environmentally Conscious Mechanical Design, John Wiley \& Soons, Inc., 25-65, Hoboken, New Jersey, USA, doi: 10.1002/9780470168202.ch2.

[32] Yuan, C., Zhai, Q., Dornfeld, D. (2012). A three dimensional system approach for environmentally sustainable manufacturing, CIRP Annals - Manufacturing Technology, Vol. 61, No. 1, 39-42, doi: 10.1016/j.cirp.2012.03.105.

[33] Waage, S.A., Geiser, K., Irwin, F., Weissman, A.B., Bertolucci, M.D., Fisk, P., Basile, G., Cowan, S., Cauley, H., McPherson, A. (2005). Fitting together the building blocks for sustainability: A revised model for integrating ecological, social and financial factors into business decision-making, Journal of Cleaner Production, Vol. 13, No. 12, 11451163, doi: 10.1016/i.jclepro.2004.06.003.

[34] Despeisse, M., Ball, P.D., Evans, S., Levers, A. (2012). Industrial ecology at factory level - a conceptual model, Journal of Cleaner Production, Vol. 31, 30-39, doi: 10.1016/j.jclepro.2012.02.027.

[35] Saaty, T.L. (1980). The analytic hierarchy process: Planning, priority setting, resource allocation, McGraw-Hill, New York, USA.

[36] Handfield, R., Walton, S.V., Sroufe, R., Melnyk, S.A. (2002). Applying environmental criteria to supplier assessment: A study in the application of the analytic hierarchy process, European Journal of Operational Research, Vol. 141, No. 1, 70-87, doi: 10.1016/S0377-2217(01)00261-2.

[37] Subramanian, N., Ramanathan, R. (2012). A review of applications of Analytic Hierarchy Process in operations management, International Journal of Production Economics, Vol. 138, No. 2, 215-241, doi: 10.1016/i.ijpe. 2012.03.036.

[38] Seuring, S. (2013). A review of modelling approaches for sustainable supply chain management, Decision Support System, Vol. 54, No. 4, 1513-1520, doi: 10.1016/i.dss.2012.05.053.

[39] Saaty, T.L. (2001). Decision making for leaders: The analytic hierarchy process for decisions in a complex world, New edition, $3^{\text {rd }}$ edition, RWS Publications, University of Pittsburgh, Pittsburgh, USA. 